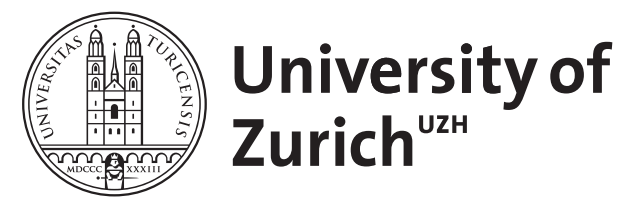

Zurich Open Repository and Archive

University of Zurich

University Library

Strickhofstrasse 39

CH-8057 Zurich

www.zora.uzh.ch

Year: 2020

Beware of deep water after subthalamic deep brain stimulation

Waldvogel, Daniel ; Baumann-Vogel, Heide ; Stieglitz, Lennart ; Hänggi-Schickli, Ruth ; Baumann, Christian R

DOI: https://doi.org/10.1212/WNL.0000000000008664

Posted at the Zurich Open Repository and Archive, University of Zurich ZORA URL: https://doi.org/10.5167/uzh-185504

Journal Article

Accepted Version

Originally published at:

Waldvogel, Daniel; Baumann-Vogel, Heide; Stieglitz, Lennart; Hänggi-Schickli, Ruth; Baumann, Christian R (2020). Beware of deep water after subthalamic deep brain stimulation. Neurology, 94(1):39-41. DOI: https://doi.org/10.1212/WNL.0000000000008664 


\section{Beware of deep water after subthalamic deep brain stimulation}

Daniel Waldvogel, MD, ${ }^{1}$ Heide Baumann-Vogel, MD, ${ }^{1}$ Lennart Stieglitz, MD, ${ }^{2}$ Ruth Hänggi-Schickli, ${ }^{3}$ Christian R. Baumann, MD ${ }^{1}$

Departments of Neurology ${ }^{1}$ and Neurosurgery, ${ }^{2}$

University Hospital Zurich, University of Zurich, Zurich, Switzerland

Practice for Neurorehabilitation, ${ }^{3}$ Zurich, Switzerland

Word Count: $\quad 655$

Character Count for Title: 61

Number of References: 7

Number of Tables: 1

Supplementary Files: 1 (video file)

Corresponding author:

Daniel Waldvogel, MD

Neurologische Praxis Luzern

Lützelmatt 3

$\mathrm{CH}-6006$ Luzern

d.waldvogel@bluewin.ch

+414120836 68 / Fax +414120836 66 


\section{Financial Disclosure Statement}

No funding was received for this study.

Dr. Waldvogel reports no disclosures.

Dr. Baumann-Vogel reports no disclosures.

Dr. Stieglitz reports no disclosures.

Ms Hänggi-Schickli reports no disclosures.

Dr. Baumann received honoraria from UCB Pharma, AbbVie Pharma, and Roche Pharma, and an unrestricted grant from AbbVie Pharma. 
We report the worrisome complaint of 9 patients receiving deep brain stimulation of the subthalamic nucleus (STN-DBS) for Parkinson's disease (PD), who lost their ability to swim after surgery. All patients had been proficient swimmers even after their PD diagnosis, but found their swimming skills deteriorated after DBS.

All patients reported being highly satisfied with the overall outcome of DBS, with very good motor outcomes (Table 1) and stable neuropsychological functions. However, they were frustrated by their lost ability to coordinate limb movements for swimming, be it for breaststroke, backstroke, or crawl. Upon systematic assessments six months after DBS and compared to pre-DBS conditions, neither neuropsychological functions nor gait were markedly changed in these patients. Routine intraoperative microelectrode recordings, macroelectrode test stimulation, and postoperative imaging confirmed correct position of the active electrode contacts in the dorsolateral portion of the STN.

Three cases are highlighted to illustrate the problem:

Case 1: This 69-year-old male PD patient experienced troubling motor fluctuations and was treated with STN-DBS. He owned a house right at the lakeside and was an experienced and proficient swimmer. Feeling confident after DBS because of his good motor outcomes, he literally jumped into the lake, where he would have drowned if he hadn't been rescued by a family member. 
Case 4: This 59-year-old female PD patient with motor fluctuations was an accomplished swimmer who had participated in countless competitions. Even after being diagnosed with PD, she enjoyed swimming regularly up to the time of surgery. Despite good control of motor symptoms after DBS, she was no longer able to swim. She regularly practiced swimming with her physiotherapist, but never came close to her previous level.

Case 5: This 61-year-old female PD patient with motor fluctuations had a lifesaving diploma and used to participate in swimming competitions crossing Lake Zurich. She was satisfied with the overall outcome of STN-DBS, having achieved good motor control without fluctuations. However, post-surgery, she could only swim for about a quarter of a kilometer and complained that her posture was "awkward" when trying to swim.

Three patients (cases 3-5) tried switching off DBS for swimming. All found their ability to swim came back immediately, with improved coordination of the limbs. However, PD motor symptoms deteriorated rapidly, therefore all decided to switch stimulation on again as soon as possible.

Discussion

Swimming is a highly coordinated movement requiring sophisticated inter-limb coordination and can be difficult for patients with PD ${ }^{1}$. Physiological studies in elite swimmers highlight 
the importance of inter-arm and arm-leg coordination for effective and efficient strokes ${ }^{2}$.

High-level motor control is known to be affected in PD, with difficulties executing simultaneous motor acts being described early, for example Schwab et al (1954) using the term "asynkinesia"3. Treatment of PD with either levodopa or DBS has been shown to improve simultaneous task execution, even to a greater extent than movements performed in isolation ${ }^{4}$. The observation that several patients lost their ability to swim was therefore unexpected, particularly since the surgical procedure was considered successful given the improvement in motor symptoms and quality of life. However, the findings are consistent with a previous case report ${ }^{5}$.

One reasonable explanation may be that DBS affects the supplementary motor area (SMA) differently than levodopa. The SMA is a main output area of the basal ganglia ${ }^{6}$, with connections to the primary motor cortex as a well as the spinal cord. Functionally, the SMA is thought to be crucial for facilitating independent movements of the limbs ${ }^{7}$, which is a key requirement for swimming. Gait is also partly managed by the SMA, however, all 9 patients maintained their walking abilities. Further studies shall determine the impact of STN-DBS on the function of the SMA.

The percentage of patients who experience deterioration of swimming abilities is not known. Our cohort of PD patients who underwent STN-DBS at the time of this retrospective study consisted of 217 patients, but we did not assess patients systematically for their 
swimming skills or loss thereof.

Until the mechanism of the reported deterioration of the ability to swim after STN-DBS is elucidated, it is crucial that we advise patients of the potential risk of drowning and the need for a carefully supervised assessment of their swimming skills before going into deep water. 
Appendix 1: Authors

\begin{tabular}{|c|c|c|c|}
\hline Name & Location & Role & Contribution \\
\hline $\begin{array}{l}\text { Daniel } \\
\text { Waldvogel, } \\
\text { MD }\end{array}$ & University of Zurich & Author & $\begin{array}{l}\text { Designed and } \\
\text { conceptualised study; } \\
\text { analysed the data; drafted } \\
\text { the manuscript for } \\
\text { intellectual content }\end{array}$ \\
\hline $\begin{array}{l}\text { Heide Vogel- } \\
\text { Baumann, } \\
\text { MD }\end{array}$ & University of Zurich & Author & $\begin{array}{l}\text { Interpreted the data; } \\
\text { revised the manuscript for } \\
\text { intellectual content }\end{array}$ \\
\hline $\begin{array}{l}\text { Lennart } \\
\text { Stieglitz, MD }\end{array}$ & University of Zurich & Author & $\begin{array}{l}\text { Interpreted the data; } \\
\text { revised the manuscript for } \\
\text { intellectual content }\end{array}$ \\
\hline $\begin{array}{l}\text { Ruth Hänggi- } \\
\text { Schickli }\end{array}$ & $\begin{array}{l}\text { Practice for } \\
\text { Neurorehabilitation, } \\
\text { Zurich }\end{array}$ & Author & $\begin{array}{l}\text { Major role in the } \\
\text { acquisition of data }\end{array}$ \\
\hline $\begin{array}{l}\text { Christian } \\
\text { Baumann, } \\
\text { MD }\end{array}$ & University of Zurich & Author & $\begin{array}{l}\text { Interpreted the data; } \\
\text { revised the manuscript for } \\
\text { intellectual content }\end{array}$ \\
\hline
\end{tabular}




\section{References}

1. Neves MA, Bouça-Machado R, Guerreiro D, Caniça V, Ferreira JJ. Risk of drowning in people with Parkinson's disease. Mov Disord. 2018;33:1507-1508.

2. Komar J, Sanders RH, Chollet D, Seifert L. Do Qualitative Changes in Interlimb Coordination Lead to Effectiveness of Aquatic Locomotion Rather than Efficiency? Journal of Applied Biomechanics. 2014;30:189-196.

3. Schwab RS, Chafetz ME, Walker S. Control of two simultaneous voluntary motor acts in normals and in parkinsonism. AMA Arch Neurol Psychiatry. 1954;72:591-598.

4. Benecke R, Rothwell JC, Dick JP, Day BL, Marsden CD. Simple and complex movements off and on treatment in patients with Parkinson's disease. Journal of Neurology, Neurosurgery \& Psychiatry. 1987;50:296-303.

5. Bangash OK, Thorburn M, Garcia-Vega J, et al. Drowning hazard with deep brain stimulation: case report. Journal of Neurosurgery. 2016;124:1513-1516.

6. Akkal D, Dum RP, Strick PL. Supplementary Motor Area and Presupplementary Motor Area: Targets of Basal Ganglia and Cerebellar Output. Journal of Neuroscience. 2007;27:10659-10673.

7. Serrien DJ, Strens LHA, Oliviero A, Brown P. Repetitive transcranial magnetic stimulation of the supplementary motor area (SMA) degrades bimanual movement control in humans. Neurosci Lett. 2002;328:89-92. 


\section{Table 1}

Outcomes in 9 PD patients who lost their ability to swim after subthalamic deep brain stimulation. All follow-up data were recorded 6 months after electrode implantation in the dorsolateral portion of the subthalamic nucleus (confirmed by microelectrode recordings and postoperative imaging). UPDRS III: Unified Parkinson Disease Motor Scale, motor part. ED: equivalence dose. D: presence of dyskinesia.

\begin{tabular}{|l|l|l|l|l|l|l|}
\hline & $\begin{array}{l}\text { Disease } \\
\text { duration } \\
\text { (yrs) }\end{array}$ & $\begin{array}{l}\text { UPDRS III } \\
\text { off } \\
\text { medication } \\
\text { post-DBS }\end{array}$ & $\begin{array}{l}\text { UPDRS III } \\
\text { on } \\
\text { medication } \\
\text { pre-DBS }\end{array}$ & $\begin{array}{l}\text { UPDRS III } \\
\text { on } \\
\text { medication } \\
\text { post DBS }\end{array}$ & $\begin{array}{l}\text { Levodopa } \\
\text { ED pre- } \\
\text { DBS }\end{array}$ & $\begin{array}{l}\text { Levodopa } \\
\text { ED post } \\
\text { DBS }\end{array}$ \\
\hline $\begin{array}{l}\text { Case 1 } \\
\text { (m) }\end{array}$ & 7 & 49 & $28 \mathrm{D}$ & 17 & 1670 & 920 \\
\hline $\begin{array}{l}\text { Case 2 } \\
\text { (m) }\end{array}$ & 5 & 62 & $24 \mathrm{D}$ & 21 & 800 & 240 \\
\hline $\begin{array}{l}\text { Case 3 } \\
\text { (m) }\end{array}$ & 10 & 40 & $21 \mathrm{D}$ & 14 & 1300 & 300 \\
\hline $\begin{array}{l}\text { Case 4 } \\
\text { (f) }\end{array}$ & 13 & 26 & $9 \mathrm{D}$ & 6 & 825 & 150 \\
\hline $\begin{array}{l}\text { Case 5 } \\
\text { (f) }\end{array}$ & 9 & 33 & $11 \mathrm{D}$ & 9 & 800 & 180 \\
\hline $\begin{array}{l}\text { Case 6 } \\
\text { (m) }\end{array}$ & 5 & 31 & 18 & 23 & 920 & 230 \\
\hline $\begin{array}{l}\text { Case 7 } \\
\text { (f) }\end{array}$ & 10 & 61 & $25 \mathrm{D}$ & $19 \mathrm{D}$ & 1650 & 800 \\
\hline $\begin{array}{l}\text { Case 8 } \\
\text { (m) }\end{array}$ & 15 & 29 & $17 \mathrm{D}$ & 16 & 2050 & 350 \\
\hline $\begin{array}{l}\text { Case 9 } \\
\text { (f) }\end{array}$ & 5 & 36 & $10 \mathrm{D}$ & 10 & 1700 & 500 \\
\hline
\end{tabular}




\section{Legend to the supplementary video}

This patient (case 4) was an athletic swimmer engaged in a multitude of swimming competitions. She continued swimming even when her PD got worse, but lost the ability to swim after subthalamic deep brain stimulation had been implemented. The video shows her problems coordinating her limbs for proper breaststroke and backstroke, which is in clear contrast to her skilled swimming technique before deep brain stimulation. 